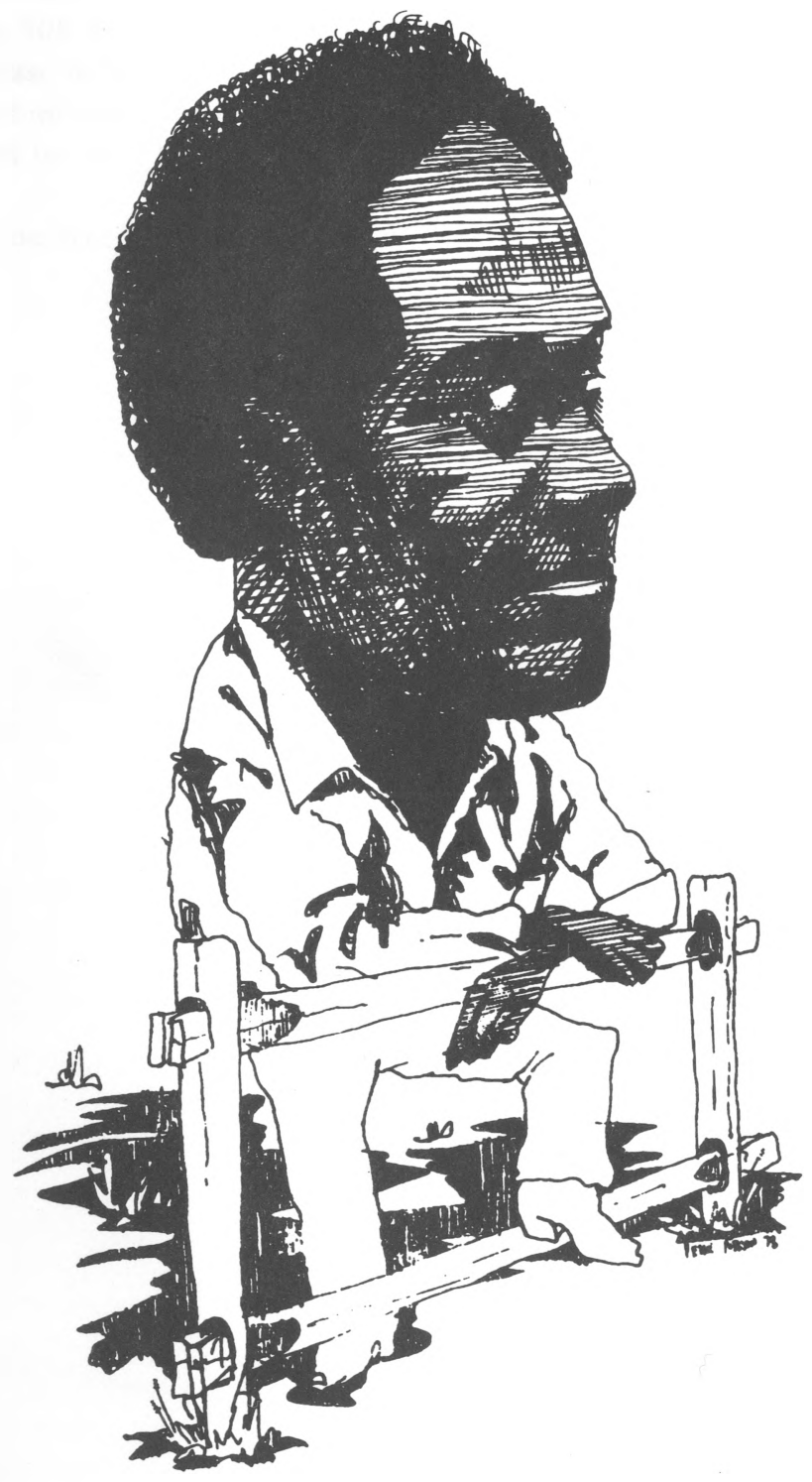




\section{INTERVIEW WITH JAMES ALAN MCPHERSON}

\section{Bob Shacochis \\ (edited by Dan Campion)}

SHACOCHIS: You agreed to give this interview because you said you were "tired of running." Running from what?

MCPHERSON: Well, not running, really. I think I speak as honestly as I can to people, but once you begin taking yourself too seriously, you get trapped in a persona, and if you start embellishing your persona by talking out of it, you get locked into that role, and often you get institutionalized. Some writers become institutions themselves. This is not the way I want to live. The price is too high. So I don't talk much, except in the classroom.

SHACOCHIS: Will you talk about how success has affected you? Is fame a curse for a writer? Has it made you self-conscious when you work? Is it something that must be overcome or could it be embraced?

MCPHERSON: I think it depends on the life habits of the individual. I used to do what I could to maintain my privacy. I read, at one period of my life, most of the time. There's nothing wrong with embracing success as long as you don't let it change the consistency of your life habits. I don't know whether I embrace it or not. If anything, success hasn't changed my life-it's teaching, more than anything else. Having to teach different courses, having to be on top of things. I was thinking today in the car, I tend to intellectualize too much, and that comes from having taught for so long. I have to stay away from that way of thinking. A writer slows down when that happens.

SHACOCHIS: Would you prefer not to teach, to be free of university sponsorship?

MCPHERSON: This is the irony. Where would a black writer go in this society? Or, as you say, a black man who writes-where would he go? He can't gain access to a community of people. He needs a community of people who share his interests, and I think a university area provides this. A black community, while it's proud of its people who do write, provides very few places where it can nurture you as a writer. 
SHACOCHIS: So this environment does nurture you?

MCPHERSON: Yeah.

SHACOCHIS: Isn't it possible just to live in such a community without having to teach? And still get the same benefits that you came there for?

MCPHERSON: I imagine it is.

SHACOCHIS: Could you do that? Are you burned out on teaching?

MCPHERSON: I think I am. In a special sense. I don't like to repeat myself, and if I have to do the same course over, the same way, without taking new ideas in, it'll be boring. One thing I disliked about Virginia was having to teach undergraduates, whereas here it's not the same kind of academic situation.

SHACOCHIS: Even though Iowa does not seem to you as oppressive as that, do you find yourself having to be repetitious in the Workshop?

MCPHERSON: No, because the students are so interested, and different. They don't make the same mistakes. The quality of the work is high. They're almost professionals themselves.

SHACOCHIS: The university atmosphere seems to be a very closed world. A lot of writers have trouble seeing beyond it.

MCPHERSON: I have no problems with that. As a matter of fact, I learned rather early that you need a support system that's normal, and so wherever I've gone I've always tried to make connections outside of the literary environment. I can still be comfortable with farmers, or blue-collar workers, without pretending or trying to act condescending to those people. When you can't, that's when you're in trouble. I'm not just talking about blue-collar workers. If you can't find something human to relate to in a person who is not doing something you're doing, then you're lost.

SHACOCHIS: What about in the Workshop?

MCPHERSON: Well, the workshop is a greedy institution. I'm not putting it down, but it's an institution that tends to give one his total identity. I was surprised at how much of a burden the students are ready to impose on the Workshop, just in terms of things you could do for yourself outside of that context. But the reputation and the efficiency of the place sometimes make a student believe that all else is forthcoming. You go to Workshop parties, think of yourself as a Workshop person-fiction or poetry, you know-and it gets so specialized. Who are you? Are you part of it all or are you nobody?

SHACOCHIS: Something else I've heard you say is that your work has not yet reached a mass audience or a popular market, that you weren't really successful-I don't fully understand what you mean by that, because of 
course you are, but is it really true that your work only reaches a small audience?

MCPHERSON: I don't know. I don't even recall saying that. But I don't try to reach a mass audience. That was never my ambition. I did a book on railroads with Miller Williams. We fought like cats and dogs because Miller wanted to cut out lots of stuff in order to make sure that the book would be popular, and I wanted to keep certain things in that I thought were interesting. No, I'm satisfied. What I want is to do better each step, do something different, and not just repeat myself.

SHACOCHIS: Would it be bad for your work to be accepted by a mass audience? Would that be in some way lethal?

MCPHERSON: No. No, it's just that I'm not trying for that. Oh, I've turned down a lot of opportunities to capitalize on my work along the avenues that allow that. I'd rather not do it. I'm not frustrated by lusting after a mass audience. What I'm frustrated about is lusting after getting something accomplished that I'm proud of. Once it gets beyond me I don't care what happens to it as long as it survives. That's what I want. I'm not looking for mass acceptance. I'm neutral. That's the best way I can answer your question.

SHACOCHIS: Frankly, the question is fuzzy to me. It might be more of a question about the nature of a mass audience, because to me, I don't know what would keep your work from having wide acceptance. I don't understand why you don't have a mass audience, whether you want it or not.

MCPHERSON: I don't think about it. I do think that certain books can be good and still have a mass audience, like Warren's All the King's Men. There are certain novels that are technically beautiful but are still popular. I think Warren's books are good enough and interesting enough to attract a large audience. When I saw him in Connecticut, he talked about writing things that everybody could read. I think this was his way of democratizing literature. Can we go on?

SHACOCHIS: Yeah, but it gets tougher, because I've been leading into a sensitive question. You're a rare occurrence-a successful short story writer who is black. I don't know how much you want to talk about it. For me, questions of race are difficult because I never know exactly how to word them, and I'm not sure, ultimately, what their significance is. But I want to know your feelings about these things. To open it up, Western literature is more or less dominated by maleness and whiteness. Do you think it will ever change? I wanted to ask that about mass audience too. Are we beginning to assimilate? Do you think being a black writer prevents you from having popular acceptance? It certainly doesn't for somebody like Toni Morrison or James Baldwin. 
MCPHERSON: No, I don't think it does. This is a tricky thing. Ralph Ellison is doing alright because his work is so great. Baldwin, I think, is a preacher. You mentioned Toni Morrison, but let's stick with Baldwin and Ellison. I think Ellison questions, and he analyzes, and he tends to get to the root of the problem. He functions more like a European intellectual. He can connect the condition of black Americans with something larger. He sees things in context. Baldwin is sort of a preacher who pronounces a last judgment on white America. I think that serves as a kind of titillation periodically for people who are secure in their power. But anybody who questions the basic assumptions is not going to reach that broad an audience. A man like Ellison, who asks those basic questions and can't be bluffed into an emotional stance-he's not a black, he's an anomaly. I think people would rather he weren't around. And I guess my ambition is to be in the same position.

SHACOCHIS: You've often been compared to Ellison.

MCPHERSON: That's because Ellison has been supportive of me. But you don't achieve mass acceptance in this culture without being diffused. Unless you are diffused, then you're likely to be limited in your appeal. It's so easy, you know. But then you end up without your self. That's the way the whole thing is set up. It's not just blacks, it's anybody. They've got to be diffused. If you can't be, then you've got a price to pay just because you question what's normal, what's right and what's wrong, what's the truth and what's a lie. But in the case of black Americans, I think, asking those basic questions is almost obligatory. In a sense, your life depends on it. You're living in a crazy country that's paranoid, in a large part because of your presence in it, and if you have a view of the whole thing, it's because you're outside, and you say "This is where I fit in, and this is where things get warped."

SHACOCHIS: This is the most difficult question I have to ask. I am sensitive to the issue, and I hope you'll forgive me for asking it. Two parts-do you ever feel that you're a token to a white literary establishment, or do you ever feel resentment from more radical black writers because of your evenhandedness?

MCPHERSON: I don't see myself as a token. I fought-I had too many fights with certain people. I'll say this, the people I fought with I wound up respecting, although I might not agree with them. But if I were a token, I'd be much more at ease and comfortable than I am now. But beyond that, Bob, my work is good. What I do is good. I teach, I write-nobody gave that to me. As for the responses of black people, no, surprisingly enough, the best review I ever got was in Essence and a black woman said, "Somebody out there's watching us, somebody out there's on to us." I'm in the tradition, I'm still in the core culture. I'm not explaining it to white folk. I don't think I'm using it to titillate whites. I've never gotten any negative criticism from black people-I never have. 
SHACOCHIS: Have you from white people?

MCPHERSON: A few nuts, but no, only from the Grand Kleagle of the California Klan, and even he tried to be gracious, sending his letterhead in a separate envelope. I can't think of any-I had a bad time with a student at Virginia who hated me - a white man. He would always disrupt my classes, always try to cause a sensation. He was sick. But that's the only time I really encountered hatred of me as a writer. Maybe it's because I use a form that everybody else avoids as much as possible. I leave the meat to the white boys (laughs).

SHACOCHIS: The meat to the white boys?

MCPHERSON: I mean the novel. But I can't say I've gotten that much negative feedback from white people. Usually the response is indifference. People have been gracious to me, all down the line. I've been lucky in that respect. I never wrote for money. I never wrote for propaganda purposes. Well, to go back to your question about my feelings about the marketplace and my color, I will just say that there are very few short story writers who end up in paperback, and very few who get a Pulitzer Prize, and very, very few who ever get popular. So I ain't complaining, I ain't complaining.

SHACOCHIS: What do you feel about minorities and their causes, and their different approaches to equality? You seem to react against angry voices and clenched fists.

MCPHERSON: I clench my fists now and then-it's healthy for your fist (laughs). I look for situations where there's a meshing, and I try to look at the values that come into conflict there. I'm going to be called a black writer until I die. But the point is that when I write at my best I try to look for the human situation, and I think whites have an obligation to do the same when writing about black folk, if they choose to write about black folk. What I'm trying to say is that there's an institutionalized classification. I used the phrase "greedy institution" a while back. That's really what those classifications come down to-institutions. They tend to define general groups in the population and assign character traits to them.

SHACOCHIS: There is an institution of literature that we're both involved in, by choice.

MCPHERSON: That's where most of the exchange should take place. There's never been a time in this country when there was not at least some exchange between artists and intellectuals. There has to be some communication. Even in South Africa that has to happen. Somebody said he once saw a white South African admire the work of a black South African artist. He wanted to look at it closer, so he reached his hand through a fence and had the fellow come up and hand the thing to him so he could look at it. But he had to have that institutional protection. 
SHACOCHIS: It has to change. There are two obvious ways, perhaps. One is through artistic influence, and the other one is through the power of the gun. Will either of these change it?

MCPHERSON: I'm not a communist (laughs). I don't know. I know you set me up to be a commentator on race relations, and I don't mean to be that.

SHACOCHIS: I don't know if I set you up to be that, but it was sort of inevitable, don't you think?

MCPHERSON: I don't have a gun. I never owned a gun. I think I don't use my writing as a gun. Any real and worthwhile change will probably come through aesthetic rather than political processes. As for radical change, I imagine the Second Coming of Christ, coming back to earth on a radical mission, and he looks at the white group, and looks at the black group, and just starts laughing. (Laughs.) A great cosmic laugh.

SHACOCHIS: So it will be a miracle that will change us.

MCPHERSON: It would have to be a miracle, I imagine. But somebody has to laugh at this. Don't you think it's funny?

SHACOCHIS: Well, I do. Yes. I laugh at it. But I also feel like crying about it too.

MCPHERSON: Yeah, yeah.

SHACOCHIS: It's inevitable that you are going to become a racial commentator. That's part of what you buy into, I guess.

MCPHERSON: No, you can resist that.

SHACOCHIS: You can resist it, but it's an important-

MCPHERSON: It's important only when the people who ask the questions are sincere. But I've seen too much of this stuff where the Ladies Auxiliary wants to do something, they invite a black person and say, "What can we do? How can we help the poor Negro?"

SHACOCHIS: That's tokenism. But I don't know how you can avoid being a spokesman.

MCPHERSON: Well, there's money in it. It's a growth industry. (Laughs.) It's really a ritual. It's a ritual drama with its own mythology. If you learn how to play the game, you can get very rich off it. What happens is that when it's in everybody's interest that things don't explode, especially at a time when you think they might, a certain commentator is needed. So that, as soon as the first riot starts, people say, "Well, we need to find out why." So they hire somebody to consult with them. Suddenly the planes get full with black people who are going to consult, consult, consult. (Laughs.) You are 
well paid and a few people read your report: "Ah, this is why," and then they kick you in the ass again. It's so manipulative. I don't want to participate in it again. It's like a wall, and everything that has been learned, even common sense, is shut off. So you start with zero-based consciousness. You start from zero all over again. And then the same questions, the same people, the same responses - and then there's no threat anymore. Close down shop. Back to normal, so to speak. It's schizophrenia is what it is. I was wondering why Ellison was sitting on Riverside Drive all through the Sixties without saying a word. He'd seen all that in the Thirties!

SHACOCHIS: Reviewers have said that you've never taken the color of your skin as an excuse for not learning the craft of fiction.

MCPHERSON: Ralph Ellison said that.

SHACOCHIS: Yeah. This reviewer borrowed it from a bigger quote from Ellison on Hue and Cry that said: "McPherson promises to move right past those talented but misguided writers of Negro American culture who take being black as a privilege for being obscenely second-rate, and who regard their social predicament as Negroes as exempting them from the necessity of mastering the crafts and forms of fiction." Those are strong words.

MCPHERSON: Yeah.

SHACOCHIS: Do you think they are unfair?

MCPHERSON: That thing has haunted me. I'll try to explain what happened, okay? I didn't know Ralph Ellison at the time. I never met him. But when I finished the book in '68, my editor asked if there was anybody I would like to get a blurb from. And I said, well, Ralph Ellison. I respected him a lot, because I had read his work. So, he sent the manuscript to Ellison and Ellison sent back a letter. I thought he was attaching a message to my back, so to speak. But I had nothing to do with it. I met him several years later, but that came back to haunt me. Ishmael Reed picked it up, and Ishmael said I was Ellison's heir apparent and things like that. But it wasn't that way at all. That's Ellison's statement, not mine. I've not since asked anybody for a blurb.

SHACOCHIS: Do you think what he was saying was unfair?

MCPHERSON: I don't want to go back to that. It would just revive old hurts and we have enough trouble as it is. But I thought that he was responding to the kinds of material that were finding their way through in the Sixties, like Cleaver. All that stuff that titillated. I've got some records here by some guys I met in Watts named the Watts Prophets. I spent about two weeks in Watts and met one of these guys. They were some of the most beautiful people I had ever met in my life, he and his wife. They were very spiritual people. And another guy from Alabama who was untutored in a technical 
way but wrote some beautiful poetry about his children and the things that mattered to him. But on the records they said, "I'm black in a white world and I'm gonna kill, kill!" And I said, "Anthony, who do you think is buying this stuff? The same kind of people who live up there in Beverly Hills getting high on heroin or speed and this is just the stuff they're getting their jollies off of." That's the kind of thing, see, so if you appeal to that group, then you alienate people who are sincere about doing what they can to solve the problem. And I think that courtship of the reductive image during the late Sixties has something to do with Ellison's comment.

SHACOCHIS: Who are your favorite authors? What are your fictional roots?

MCPHERSON: I like popular novels, popular storytellers. Some people don't like to admit this, but I read John O'Hara religiously. I did. I read all his stories. I read Hemingway and Fitzgerald. I read all of Damon Runyon. Jack Leggett was talking about a popular novel named Anthony Adverse. I read it four times. I read all the popular novels of Mika Waltari. He did one book called The Egyptian, one called The Etruscan, one called The Wanderer. I read everything he wrote. I'm still evolving. My goal this winter is to read all the Russians. I mean all of Dostoevski.

SHACOCHIS: So you would point to the paperback rack in the drugstore for providing your impetus and inspiration.

MCPHERSON: Yeah. A lot of guys won't admit it, but that's where they started out too.

SHACOCHIS: I'll admit it for myself.

MCPHERSON: I know I used to go to the Salvation Army to buy copies of Balzac and I used to buy comic books there, and Maupaussant, people like that. But you begin in a drugstore, buying a novel that has a pretty picture on the cover, something that attracts you. Then you say to the public, "I never read anything but Proust anyway." But it's not true.

SHACOCHIS: You said you think some of your stories in Hue and Cry or Elbow Room are slight. Which ones are your favorites? Which ones mean the most to you?

MCPHERSON: "A Solo Song; For Doc" is my favorite story. About railroad waiters.

SHACOCHIS: How autobiographical is that? How much imagination is there, how much observation?

MCPHERSON: That's completely made up. Made up in the sense that-well, I worked on the railroad for four summers during college. Just sitting around the table after breakfast, after lunch, all the waiters would talk, they'd tell all these stories. They'd just get into it-it's tradition being passed on. You 
don't think about it, but at some point it'll come back to you. There were about one hundred or two or three hundred stories I knew from them, that I just picked up listening to the waiters talking.

SHACOCHIS: You refuse to be a propagandist in your writingMCPHERSON: So far I have. I just may try and do some (laughs).

SHACOCHIS: Do you have any causes you support, in or out of fiction, besides honesty and humanism?

MCPHERSON: No. I don't like to see people hurt. A therapist told me I had a neurotic need to rescue. I don't like to see anybody get shafted. I remember one time I was walking down the street in Baltimore and I saw a street auction. All these sharks with these tailfin Cadillacs parked in the slums. They were about to bid on this house rented by an older black couple who were sitting on the porch. All the sharks were white, as was the auctioneer, and the people sitting on the porch were dressed in their best clothes. I said to myself, "Just look at this. This is what slavery was like." It wasn't like a buck on the auction block all greased down, muscles rippling. It was people in their best clothes, and they were placed in the hands of people who didn't care about them. I didn't have a penny but I walked into the crowd anyway, and the bidding started. I started bidding, raising the amount by five hundreds. The guys thought I was a shill placed there. Somebody would say $\$ 4,000$. I'd say $\$ 4,500$. So they'd back off. There I was stuck with this house that I couldn't pay for. I did it instinctively. The therapist says that's neurosis. I don't believe in causes, but I don't like to see that kind of thing happen.

SHACOCHIS: Just in terms of technique or approach, in fiction at least, introspection seems to be a cause of yours. Does that make sense?

MCPHERSON: What else can anyone be but introspective?

SHACOCHIS: I'm not sure. Isn't it more or less the opposite of realism? Realism would be more journalistic, objective-observing something and writing it down. Introspection would be the opposite approach. The writer or narrator exploring his own self, rather than examining the outside world. I know you are certainly realistic in your-

MCPHERSON: No, I've been criticized for that. It's been said that I see outside things only in relation to what I am. But that can't be helped. I wasn't aware of it, but that's the way my life is. I'm an individual, so that's what I do. Not consciously, perhaps.

SHACOCHIS: Why did you go to Harvard and enter law school?

MCPHERSON: Why not?

SHACOCHIS: Did you want to be a lawyer? 
MCPHERSON: I had a disadvantage. I promised my grandmother I'd become a minister. That's why she helped me go to college. And I thought law was even better. But I had an illusionary perception of what the law really was. I really thought that a lawyer was a good guy who helped people. And then, I couldn't refuse the opportunity to go to Harvard. At that time I was trying to figure out what was going on. I took courses in the legal process and in jurisprudence. The teacher was a fast talker and talked about all these abstract issues. I sat next to a man from Wisconsin named Jim Himmer. During one lecture I turned to him and said, "Jim, I don't understand what the teacher just said concerning the issue." Jim said, "Don't you understand, man? This is all bullshit." You know, he meant the courses in jurisprudence and legal process. The meat and potatoes was taxation, corporate law, estate planning. You see, the school I attended brought in the sons and daughters of the middle class to perfect their skills to be moved into law firms to help those great fortunes pass from one generation to the next. I was being trained for that-unhappily. I didn't know any black folk who had money (laughs). So I thought I'd be a minister of law, but you can't do that, so I got out. Where are you going to help people?

SHACOCHIS: Criminal law?

MCPHERSON: That's what I wanted to be. I prosecuted for a little while in the Boston courts. It was my last year in law school. They had a student D.A. project. I went down to the court and I was allowed to prosecute a case or two. I remember there was this Italian kid who had stolen a Cadillac and driven it from Boston to the suburbs and they caught him. I was in the conference room when the arresting officer came in and said, "We've got this kid cold. So now, you ask me this and this and this and I'll say this and this and this. And we'll get it over with." The kid had a lawyer with him. He came up and said to me, "He got lonely and wanted to see his mother. He got drunk and stole the car to go see his mother." Well, I could believe that. I could understand that. My policeman just had the facts, but I could see the things that motivated the kid to do that. So I couldn't stand things like that.

\section{SHACOCHIS: What about defense?}

MCPHERSON: You can't make a living defending people. It drives you crazy, because the system is so set up that it's automatic. Oh, I did a long article on housing discrimination in Chicago back in 1973. It took up almost an entire issue of Atlantic. That article probably took about a year of my life. Nobody read it and people condemned me for writing it. But one of the issues was these people, black people, were confronted by discrimination institutionalized by the FHA, which said that anytime more than a few black people come into a neighborhood, it's changing and banks should not risk any loan money there. That was its policy since the Thirties. They couldn't 
get mortgages. I mean, if you come up from the South, and the Southside is full of black folk, where are you going to go? So blockbusters moved in and scared the whites out of other areas. But since the area is changing, there's no mortgage money, so they sell the house to people on contract. They will buy a house that's worth maybe $\$ 50,000$, pay $\$ 5,000$ for it, and sell it for $\$ 65,000$ to a black person on contract. It's like the easy payment plan. You know, you don't get any equity. If you miss one payment they take it all back from you. You're like a slave. So the people finally challenged this. They went on strike and refused to pay. And one of the issues was the seller took them to court to obtain payment, and the people said, "Well, we want to pay, but our case is in court. Let us pay the money in escrow. Anything but to give the money directly to these sellers who are cheating us." The judge said "No. The only issue is, 'Do you owe?' If you owe, why haven't you paid? If you haven't paid, get out of the house." So you had all these mass evictions of people. But the issue was a human one, and the legal system can't take that into account.

SHACOCHIS: It can't. It's process.

MCPHERSON: Right. It's all process. It's all nuts and bolts. Why would I want to work in that kind of mess?

SHACOCHIS: But you thought you did. After all, you did go to law school.

MCPHERSON: Um hmm. One of the things I got out of law school that I really value was meeting a man named Paul Freund. He was a great man, a great teacher. He was a Carl M. Loeb University Professor. That meant he was qualified to teach in any department of the university. He didn't just teach constitutional law. When he talked about censorship, he would bring in Ulysses. He knew the book well. He would talk about art! He wrote articles on law and art. He was a great man. I saw him in the hall. I said, "Professor Freund, I just wanted to say hello to you." He said, "What's your name?" I said McPherson. He said "Oh, you're the one who writes for Atlantic." I said yes. He said, "You've gone beyond the law." And that's all he said to me. Then, last summer when I was here I got a note from a lady in Richmond. She said she had been to an ABA meeting and she had dinner with Professor Freund. And he made her swear to tell me that he had written a letter for me to get the McArthur Award. When I look back on my law school career, the best thing that happened to me was encountering Paul Freund because he's the kind of man who would say, "We have very bright students who know all of the answers, but none of the questions." It's that kind of mind that you run across just once in your lifetime. And that makes you think that it's possible to do something "beyond the law," so to speak.

SHACOCHIS: You were already writing for the Atlantic Monthly when you were in law school. 
MCPHERSON: I sold my first two stories to them the last month I was there.

SHACOCHIS: How old were you?

MCPHERSON: Twenty-four.

SHACOCHIS: Why did you decide to become a writer?

MCPHERSON: Why not?

SHACOCHIS: It was already in your mind there in law school. Let me rephrase it so I can get something out of you. What made you think you could become a writer?

MCPHERSON: What made you think you could become a writer?

SHACOCHIS: Well, that's still in doubt.

MCPHERSON: No, you're a writer, but what made you think you could become one?

SHACOCHIS: I suppose because I seemed to do it well, and there was joy in that.

MCPHERSON: All right, there's that. And being able to use my imagination. I remember I had a job in high school. All through high school I would have to go to work, after school from 3:30 to 7:30 at night and all day Saturday, bagging potatoes, putting Irish potatoes in five-pound and ten-pound bags. That was my job in produce. And so I never had time for dates. But what I did was use my imagination, because you can't do nothing but work and not use your imagination, or you die. I think it was looking at people, or just thinking, that kept me alive, so to speak, in my imagination. I suppose to find a way of expressing that, I chose writing.

SHACOCHIS: The freedom of it is also something that attracted me. Not that being tied to your typewriter or pen and paper day after day is especially a free occupation, but there is a lot of freedom, room to move and grow, inherent in the profession of writing. Or rather lifestyle, not profession.

MCPHERSON: Yeah, if you can publish. But it's also a way of dealing with things. You asked me why I'm introspective. A lot of mean things have happened to me, and the only way I can deal with them, or beat them, is to take it inside myself, turn it over and look at it and try to humanize the experience, try to understand why it happened. I have that capacity, and I think without that capacity, you go out and shoot people or things like that.

SHACOCHIS: Do you think the role of the writer extends beyond that personal process?

MCPherson: You mean into society? Well, I'd have to give an ideological answer. I think that because I'm classified as a black writer, and because I 
come from a group of people who are largely inarticulate and because society has erected certain norms and walls and ways of distorting their image, I sort of have an obligation not to write propaganda but to re-create them the way I know they are, because they can't do it for themselves. And that's something we shouldn't have to do. I wish I didn't have to struggle to understand black people who hurt me. But I have to understand why this happened, and what warped them a certain way.

SHACOCHIS: There isn't always a sociological explanation for individuals, or for injustice, is there?

MCPHERSON: I should say so. That's true. Evil is-I never understood it until these last two or three years. It's smooth, and it's ever-vigilant. It's always on the case. I didn't really believe in evil until this last year or so, but it's steady on the case.

SHACOCHIS: Have you read Anthony Burgess' Earthly Powers?

MCPHERSON: No. I want to, though.

SHACOCHIS: It's an excellent evocation of good versus evil.

MCPHERSON: But I will say categorically that evil is a dirty muthafucker (laughs).

SHACOCHIS: It's there, and it's something that-sociology or not-is there and working. It might matter if your mother beat the shit out of you when you were a kid, but I don't think it matters whether you're black or white or middle-class or upper-class or whatever.

MCPHERSON: I've got two copies of the Daily Word over there on the table. Mrs. Julia Smith got me to subscribe to it. And I said to her back in the Fall, "Well, I'm glad I moved to Iowa City. I don't have any enemies there." She said, "How do you know?" She said, "You can't run from trouble. Some people are going to dislike you just for their own personal reasons." But she said if you read the Bible and think good thoughts, God will place a shield around you and they can't harm you. It's like evil is not in any one place, it's everywhere, and you have to do all you can to protect yourself from it. And sometimes I think probably prayer, or at least having the faith that God will protect you, is the only thing you can do. I went to church this morning. I was very depressed. But after communion when you come back to your seat, before you sit down you say a prayer, pray what you have to pray. A church is no real sanctuary against that, but it's good for you to be sharing something positive with other people. But once you become aware that evil does exist, you get frightened. You realize that what we call reality is just a stage, with invisible props. You push a little bit and you see those props.

SHACOCHIS: Fear is the better vantage point to have than simply naiveté. It prepares you to deal with adversity. 
MCPHERSON: Yeah.

SHACOCHIS: It's also something that can help strengthen. You're a religious man. Does that have any effect on your writing?

MCPHERSON: No, I'm not a religious man.

SHACOCHIS: You find value in religion, true?

MCPHERSON: I think not in organized religion. I think that if you maintain a belief in a divine principle it can make life easier for you. Easier in the sense that you don't tax yourself by trying to account for what happens to your life. You accept the possibility of mystery in human events. And that gives you a certain amount of peace. If I didn't have that I probably wouldn't be around now. It's not religion in the sense that I would say I'm a Baptist or a Methodist or an Episcopalian or I believe in a virgin birth. It's just that I believe that if there is no mystery, if life is what they say it is, I don't want to be around. I can't explain it better than that.

SHACOCHIS: I share the same belief but I wouldn't go to a church to affirm it.

MCPHERSON: I just started going to church last year in Charlottesville. I didn't go to church from the time I finished college until then. But these are hard times, pal. Hard times in the sense that-oh, you see all this viciousness, this random evil. It's like people have lost the capacity to make moral distinctions. I saw on the news last week that a kid out in California raped and killed his girlfriend and then took his classmates to see the body. And nobody said a word. It's like they lost the capacity to feel guilt or remorse, and it scares me.

SHACOCHIS: Is it really so extensive, or is it just that it is so publicized now, the media are so omniscient and effective, and that the population is now so big, so that the proportion is the same, and these acts have always been committed, that society has always been this way?

MCPHERSON: No. One thing that happened during the Sixties was that the humanities got pushed aside. Science and technology took ascendancy. The unrestrained, unrefined human soul is a vicious thing, it really is. And I think that that excess, when the discipline of the humanities was neglected and allowed technology to gain the upper hand, unhumanized technology. So now you go over to the mall-right next to the movie house, there's a little room where you got pinball machines, but they got these machines where little kids learn how to hit a pedestrian, you know, or shoot somebody. What's that doing to them? All that home video stuff, what's that doing to people?

SHACOCHIS: Ferdinand Marcos just outlawed video games in the Philippines. 
MCPHERSON: Did he?

SHACOCHIS: It's a twelve-year sentence if you have one or are caught playing one. Hardly an appropriate answer to the problem.

MCPHERSON: I had a student in Virginia who was just a rotten kid. I talked to him and asked, "Don't you feel anything?" He said, "No, I don't feel anything." It's out there, people who lack the emotional depth to feel guilt, to have a conscience. That's why when you asked me about guilt the other day, I chuckled. I don't see much of it around. I don't.

SHACOCHIS: Nevertheless, a lot of people I know seem to be almost crippled by guilt. I'm not talking about racial guilt-just guilt as a reaction to behaving irrationally and hurting other people.

MCPHERSON: I feel that kind of guilt myself.

SHACOCHIS: Okay, let's move on. You came right from Harvard to the Iowa Writer's Workshop. Why? What did you hope to accomplish here? What had happened? You were in law school, you abandoned that and made a commitment to be a writer and came to Iowa.

MCPHERSON: I didn't abandon it. I finished law school. I finished in June of '68 and came here in September.

SHACOCHIS: Right. But most graduates from your class in the Harvard Law School in September of '68 had taken their bars and were in practice. You changed commitments. Or finally made a commitment.

MCPHERSON: Yeah, well, I wanted to write. I had just sold two stories to Atlantic. I remember, I went up to see George Hughes, he was a classmate of mine. He was a year ahead of me, had finished the year before. Now this is not invention, it's the truth. I was wrestling with whether I should try my hand at writing or go ahead and become a lawyer. And I went up to see George-he lived out near Watertown. He had just got married and his parents were there. So we were talking in his apartment, you know, saying what we were going to do. George had gone to Yale and had gotten overrefined and he was really prissy. But his father was an old working-class Irish Catholic. And the old man said, "Well, Jim, do what you want to do, what's best for you." I was walking back to Cambridge and I passed a graveyard. I was looking at the gravestones, and one gravestone said on it McPherson. I said, "That's a sign. I'm going to end up there anyway (laughs)-might as well do something that's meaningful to me." So I spent that whole summer writing and came here in September.

SHACOCHIS: Who were your teachers here?

MCPHERSON: Bill Fox, Richard Yates, people like that. 
SHACOCHIS: Do you think teachers in the Workshop have a great influence on their students?

MCPHERSON: Well, you can, if you don't watch yourself. I don't want to influence anybody except to get them thinking about certain things. In terms of style, I guess you can, because some students are also caught up with trying to imitate. So you have to be careful about pushing your own sense of style. But yeah, it stands to reason, anybody standing behind a desk has-I make a point in my classes of not sitting at the place where the power center is supposed to be. I want to be as democratic as possible. But if you insist on that prerogative, you run the risk of undermining the development of the student's own sense of style. You can add to it, but it has to be the student's own.

SHACOCHIS: Do students influence teachers?

MCPHERSON: That's a good question. (Pauses.) Only if they're pretty (laughs).

SHACOCHIS: What did the Workshop mean to you as a student?

MCPHERSON: I didn't have much contact with the writers here. I knew a few, but I sort of had my own life. But it did-not the Workshop but the Rhetoric Program-give me the opportunity to go into a classroom and teach for the first time. And I began to develop skills there that allowed me to teach in other places. It gave me that. It also gave me a base, a home base in Iowa City. Oh, a friend of mine in Boston, when I told him I was coming back here-he was my old teacher, a man named Alan Liebowitz, he teaches at Tufts now. He taught me at Harvard when I was a law student, and we've been communicating since about '68, when I was first here-he told me he had been looking through all my letters, and that he had seen that Iowa City was the one place where I was happiest. So there was something here that allowed me to feel at ease.

SHACOCHIS: Teaching Rhetoric is something that can influence and help your own writing since it compels you to analyze the process of writing. Do you feel that your writing benefited from the Workshop itself, or was it just a place to be?

MCPHERSON: Well, I had published a book before I ever came here.

SHACOCHIS: Hue and Cry?

MCPHERSON: Yeah. But it did give me exposure to a critical process, the way students responded to manuscripts in class. And I suppose it gave me what Cambridge did not give me, and that was access to a community of writers, people who were doing the same thing. That's something that you need, I think, sometime.

SHACOCHIS: You wrote Hue and Cry when you were a law student then? 
MCPHERSON: I wrote that book my last summer in Cambridge.

SHACOCHIS: You wrote it during the summer-one summer's work?

MCPHERSON: Yes.

SHACOCHIS: (Laughs.) It takes an entire summer for me to write one story.

MCPHERSON: I couldn't do it any more, but I did it. I had a tremendous amount of energy in those days.

SHACOCHIS: To what extent can a writer, or a student/writer, become a product of a workshop?

MCPHERSON: I don't think it's as simple as the Workshop influencing your style. I don't think that's possible. I think that if you come in hoping to get an MFA so you can teach, you are now a product of the Workshop. But as far as writing goes, I don't see how it can do that.

SHACOCHIS: Then the Workshop, in your opinion, doesn't have a tendency to homogenize, or create schools of writing, as in schools of thought or schools of poetry. There are schools of poetry, aren't there? The Robert Lowell School, the Donald Justice School, the Philip Levine School of Poetry. They each influence other poets in the traditions and style and aesthetics they themselves established or worked with.

MCPHERSON: Yeah.

SHACOCHIS: Does that happen in fiction writing?

MCPHERSON: Not in an institutional way. It happens because the teacher is there, not because of the institution. There's a great quote I used one time from André Malraux. It says, "The individual stands in opposition to society but he is nourished by it. And it is less important to understand him than to know on what he feeds." Every writer is an individual; he has to be. And every writer is going to look around for models. And models are never institutions. They're always other writers. I was accused of being Ralph Ellison's protégé, but what Ellison was was a mentor. He gave me certain ideas that made me proud to be a black American. I mean it's as simple as that. He was saying our influence is everywhere. And he hasn't propagandized anything. So I said, "Well damn, here's the perspective I've been looking for." The ideas I got from him I've used, I think, but my style is my own.

SHACOCHIS: What is the role of the teacher/writer in teaching new writers? Is it a bogus role? Is it just to be close by, is it just proximity?

MCPHERSON: I suppose it is. I don't know. I know that if you study the lives of great writers you see that they've always had contact with writers that inspired them. And I suppose that since there are no salons in this country, 
places where writers can get together, the university tends to provide a facsimile of that.

SHACOCHIS: What are the pitfalls of that trend, and also, what are the advantages?

MCPHERSON: One pitfall is that you get your ego stroked by students to such an extent that you stop writing. That's the worst thing. Another pitfall is that you can get comfortable. You can get so comfortable that you get institutionalized, and you start turning out these novels dealing with the academy.

SHACOCHIS: Workshop stories?

MCPHERSON: Well, not workshop stories, but novels dealing specifically with college life, university life. The thing you want to do is maintain your separateness. Be a traveller. Get on a bus and go someplace. Walk the streets, just to learn something. If you become too much a part of the academic community, you run the risk of closing out the rest of the world and seeing life only as it's played out in that small arena. There are advantages in a university job-I can think of no other employment that allows you a month off for Christmas, summers off, and you go in about two days a week, and you read books. The man is going to pay you to talk about books!

SHACOCHIS: Hurray for the university.

MCPHERSON: Yeah. I mean, I'm going to read books anyway, and a man's going to give me money to do that!!??

SHACOCHIS: Tell me this. What's the most important lesson for a student writer to learn?

MCPHERSON: I don't know. What is the most important lesson?

SHACOCHIS: I don't know for sure but-

MCPHERSON: Why'd you ask me that silly shit (laughs)?

SHACOCHIS: Well, it might not be silly. What could you say?

MCPHERSON: Dot your i's. I don't know.

SHACOCHIS: I'm not sure that it's a silly question.

MCPHERSON: Well, I want to say, try to tell the truth.

SHACOCHIS: That answer makes it not silly any more.

MCPHERSON: But that's a cliché, because the world will hate you if you tell the truth. I mean the truth as you perceive it. I'm not saying that you have the monopoly on truth, but if you say what you see, people hate you for it. I think anybody who wants can tell the truth. When I say truth I mean, 
what you really think and what you really feel, what's important to you at the time.

SHACOCHIS: Well, you see, that's taken away the silliness of the question.

MCPHERSON: No, because you set me in a position of offering advice to writers, which I would prefer not to do. I just said that because that's what I would want somebody to tell me.

SHACOCHIS: You are in as much of a position to offer advice to writers as anybody. Even more so-you're getting paid for it.

MCPHERSON: Hemingway told somebody-it's the same advice-he said you should have a built-in shit detector with a manual crank in case it malfunctions. That's good advice.

SHACOCHIS: The form of a story seems to be crucial to you. What are your motives in choosing a form, or experimenting with form?

MCPHERSON: I think that every story has its own form. It's just one way a story can be told. But if you try something the wrong way, you're not going to get all you can get out of it. So what I do is start by trying to find a point of view that best tells the story. That's hard. That's the hardest part about it. A story can be worked for years, but if you don't have the point of view, it won't be written. Let me think of a story-the one called "The Story of a Scar." I tried to write that story in California right after I got out of the hospital. I saw this woman with a scar and I couldn't figure out how she got cut that way. What I wrote was like, um, trash. It was like trying to account for a lower class way of life I didn't know anything about. Then some time later my sister told me about a man who cut his girlfriend in the post office. The two things came together, and I could write the story then. In fact, I gave my sister half the money I got for it.

SHACOCHIS: Well, that completed the logic of the story. But did that reallylet's say form just in terms of the structure of the prose-did it affect that?

MCPHERSON: Well, when you think back on yourself, sitting in California, writing a story about life among the lowly, and then you, or that persona that you were, becomes a character in the story who's condescending to people who have their own reality, you see. And that stems from a problem with language - like high language presuming to judge a low language.

SHACOCHIS: A lot of your narrators seem quite affluent. Are they actually alienated from the other characters they encounter?

MCPHERSON: Affluent?

SHACOCHIS: Yeah. Or affluent and well, distant. They have a distance, whether it's an affluent distance or a- 
MCPHERSON: Linguistic difference.

SHACOCHIS: Linguistic distance, or an intellectual distance.

MCPHERSON: That's what I was concentrating on. You're talking about Elbow Room, right? What I was working with there-I had taken a course from Henry Nash Smith at Berkeley when I was out in California. One thing he dealt with in his books was the relationship between vernacular language and social structure. That is, the American vernacular, the common speech, evolved and considered itself in opposition to the formal and certified mode of speech. Now, each level of speech contains its own values, its own value system. And it was fun to be able to trace the development of that language from its origins in the pre-Revolutionary War period to the time when it received its celebration in Mark Twain, in Huckleberry Finn. But the issue, and it's still unresolved, is whether vernacular language and the values it seems to affirm, are really as solid as the values presented in high speech. So what I was doing in Elbow Room was seeing it in terms of "high" linguistic habits and the values embodied in those habits, put in opposition to the linguistic habits of vernacular speech and its values. Most people saw it in terms of the black middle class and the black lower class. It wasn't that way at all. I was just trying to show the presumptiveness and the arrogance of that high speech, especially when it confronts the reality presented by the low speech, which is more valid. Now the danger is that the low speech can be just as condescending and reductive as the high speech. What do you do when you get a Huckleberry Finn who speaks the vernacular, and you're about to celebrate those values and about to dramatize the decadence of the learned values, and you run into the Duke and Dauphin, those confidence men, who are also vernacular characters? You see what I'm trying to say? That was Twain's problem. What do you do? So you stop the novel, and you wreck the raft, and you put Huck ashore away from Jim, and he goes and tries to get back to this traditional community. And then Twain says, Well no, it's still decadent, so you go back, resurrect the raft, you find Jim and take him back. You see, but you can't resolve it. So in the end you say-I won't work out the implications of this because I can't, but I'll just end the novel with another melodrama and have everything come out fine. Jim is freed by his owner, Tom Sawyer appears, and Huck Finn reverts to being a boy again because he couldn't see anything better in the values represented by the common speech. That was Mark Twain's dilemma. There's a big thing in Huckleberry Finn where, in the midst of celebrating the common speech and the values it's supposed to convey, Huck goes to an Arkansas town and a drunk man named Boggs comes through and he says, "Where's Colonel Sherburn? I'm going to kill him because he insulted me." He arrives at the Colonel's house and says, "Come on out." And the Colonel, an old Southern aristocrat, comes out and he says to Boggs, "If you're in town when I come out again, I'll shoot you down." And he walked back into his house. Then 
people told Boggs he'd better leave town. He was just about to leave, I think, when the Colonel comes out again and shoots him. Then he goes back in his house. The townspeople are outraged. They gather together in a lynch mob and go to the Colonel's house. He comes out and says, "The idea of you, lynching anybody. I've lived in the North and in the South, and I know the average all around. The average man is a coward." And then they all left and he went back in his house. Well now, that's Twain. That's the same persona that later appears in The Man That Corrupted Hadleyburg and The Whole Damn Human Race. That's Twain.

SHACOCHIS: His arrogance?

MCPHERSON: Well, it's not so much arrogance as it is a confession that although the values implied by the proper speech of his day didn't quite fit reality, the speech and the values of the vernacular class weren't necessarily any improvement. What are you going to do? You wreck the raft.

SHACOCHIS: Well, it made him a cynic. Is it making you a cynic also, or are you finding that the values do fit better than Twain realized?

MCPHERSON: They don't fit better, but what I find is that it's not one or the other. It's not a class thing or a speech thing. What's needed is a kind of civility, a code of manners.

SHACOCHIS: A code of decency.

MCPHERSON: All manners are a stylization of tension. Like in the South, even in the worst, most racist communities, people both white and black say to each other, "How are you?" "Nice day." You know. It's a way of acknow. ledging your presence, and also acknowledging that you have to cope because you're living together. That's what's needed, and it's not just needed between black and white; it's needed between white and white, black and black, and men and women, too. We need a code, some kind of civility.

SHACOCHIS: Talk about the short story as a form itself.

MCPHERSON: The short story is the only indigenous American form. You don't have any great novels coming out of this country because it's too fragmented, made up of too many different groups. Who can see the whole picture? All you can do is give little reports from this section, that section.

SHACOCHIS: Do you think the short story again will go under, or do you think it's up for good? It seems exceptionally strong now as a form. And, like jazz, we're heralding it as truly American.

MCPHERSON: I think that when people are in trouble-this country is in trouble-you always go back to your basic premise. And I think jazz will always be here, just because it grew as a form out of our basic American spirit. If you go into a record store you can see a whole wall full of rock and 
new wave and that kind of stuff, and that's for a decreasing piece of the audience, and the other stuff, jazz, is still around. I think the same is true for the short story form. People have to get some grounding, some sense of what the culture's basic orientation is. So you go back to familiar forms. That's all I can say.

SHACOCHIS: How important are the small literary magazines?

MCPHERSON: They're very important, and they always have been important. This thing I read on Williams Carlos Williams-he never got a single poem published in any commercial publication. And this was a master! He had to rely on the small magazines all the time. They allow a lot of people to survive. The good thing about National Endowment is that it allows those magazines to live, so that there's room now for work that will not be touched by commercial publishers.

SHACOCHIS: How did you get involved in the book Railroad that you edited with Miller Williams?

MCPHERSON: In '73 and '74, I was living in Rhode Island. This was a time of extreme racial reaction, and I had been trying to convince somebody, an editor, that it was in everybody's best interests if the country could decrease its polarization, if he could take a Bicentennial stance to affirm those things that we all had in common. And I said, "All we have in common that I know about is the Constitution, and our memory of the railroad, and if I can write something for you that could feed everybody into that central symbol and show you how it looks, maybe you will take the idea." So I wrote-that's when I was trying to save the world-I wrote a long long long essay, feeding everything into it; and he finally, after some long delays, said, "I don't know what you're talking about." So the essay sort of laid around. And I felt a lot of shame because here I was, a colored boy from Savannah, trying to say, "We have things in common that can hold us together as a people, as Americans." Anyway, later on when I was in Spokane, a year or so later, I met Miller Williams. We started trading railroad stories so we decided to do a book together. We got some money from Random House. If you look at the essay in the book, the form is that of a train, even with a caboose. I just had fun doing that. To answer your question another way, the real inspiration for it was my attempt to argue with a book by Leo Marx, a book called The Machine in the Garden. It was a study of the pastoral ideal. The idea of the pastoral comes down from the Greeks. The conflict was between this old world notion of the sublime and the hard facts of American technology in the eighteenth and nineteenth centuries. Marx's idea was that nineteenth century American writers had great difficulty reconciling the pastoral, which we inherited from the Greeks, with the hard facts of an industrial democracy. And I said, "Yeah, but whenever there's a conflict, a thesis and antithesis, there's always a synthesis someplace." And I said, "Well, what about the 
central symbol of nineteenth century industrial technology - the railroad. What do we do about that?" And then I began going through the literature and looking at the vernacular response to that artifact. What the common, untutored people had to say about it, not the people who had preconceived notions about the nature of art. People who had no choice-what they had to say. And I found that they had an instinctive fear of it, and also an instinctive desire to recontextualize it, to take it apart and redefine, reinvest it, with things that had meaning and value. And that was a kind of art. And that's why I wrote the long essay and edited the book. But who am I to argue with Leo Marx?

SHACOCHIS: You're a voice, just as he's a voice. Who's anybody to argue with you?

MCPHERSON: I was proud of that book because I had the capacity to write about things beyond the immediate experience of my color. And that's what I love, because I found that I could master a certain amount of material. But then the message comes back, "Stick with what you know."

SHACOCHIS: That's an ignorant message. You know that.

MCPHERSON: But if most people think that, it's reality.

SHACOCHIS: I don't think most people think that.

MCPHERSON: Um hmm. Well that's what I really want. That period was the best in my life when I think back on it. I had all these books from Brown University library. I was reading them and I was really beginning to put Marx's, Leo Marx's, ideas into the American context. He's really European. I was able to say to myself, "I'm an American. This is mine." And I was saying to him, "There's something you don't understand about being an American." It was like an expansion of my mind, so to speak. And I envision, maybe a hundred years from now, if the country lasts that long, a black American who wants to write a book on anything will have the freedom to do that without people saying, "How does this relate to your color?" That's what I really want to see.

SHACOCHIS: Are you interested at all in the Third World? Is there any moral obligation, because writers use moral ammunition, is there any moral obligation for an American writer to look beyond his own house? Considering the way the world is today?

MCPHERSON: Well there's a lot of change going on outside of this country, but inside this country we can't seem to get a handle on it. I don't know what the Third World is. I think it's fiction.

SHACOCHIS: It's just a convenient term.

MCPHERSON: This is dangerous to say, but if the Third World has any power, 
it's politically advantageous for black Americans to say, "I'm Third World." Well I'm not after power myself. I just want to see things. There's an old Negro saying, "You may be my color, but you ain't my kind." I guess what I want to do is find my kind. It has nothing to do with color.

SHACOCHIS: If you insist on color, and the Third World continues to develop the way it is, that would be a very interesting revelation for white America, because the stronger the Third World becomes, the more voice they have, the more they expose themselves to white America, the more white America has to come to terms with themselves as the minority, the global minority.

MCPHERSON: Then that means doomsday for black Americans because we are the scapegoats for all the frustrations, you see, and the color fears they have for what's out there. That's taken out on black Americans. You know what sustains me, what used to sustain me, is the story in the Bible about Joseph and his brothers. If there is a God, He must have had some reason for the sale of Africans to Europeans over here. If you think about it, we're the only people who didn't come here voluntarily. I mean, we had to make our own way. And there must be some part of God's plan that accounts for that. When Andrew Young was making these statements, he was trying to create a bridge between this country and Africa, this country and the Third World, and they shut him up. They didn't want to hear it.

SHACOCHIS: Some people listened to Young. At least that's a step.

MCPHERSON: All those guys in the foreign service should be thrown out and they should put in some old dining car waiters (laughs).

SHACOCHIS: In your article "On Becoming an American Writer," published in the Atlantic Monthly, you say that you're the product of a contractual process. What does that statement mean?

MCPHERSON: If I recall that article, I think when I was writing it, I recalled that my mother and father never did talk about the mean treatment that they received from white people. I remember my mother saying that her father was a sharecropper on a white man's plantation. She said that the owner fired the white overseer and gave her father the job. And she said the man that was fired swore he'd come back and kill her father. She said she remembered her father sitting on the porch all night with a gun in his lap waiting for the man to come back. That's the one thing she talked about. Another thing was that she was telling me when I was a child about World War II, and about how the Japanese would be hiding in trees to catch the Americans. And it came to me later that she was talking tongue-in-cheek about Reconstruction, about what the white South did to reclaim its power. But she had put it in a context that she could deal with. My father never talked about it. Well, there was a reason for that. It was grounded in, I think, a religious belief in progress and the correctability of people. And they 
refused to burden the younger generation with the baggage of their own frustrations. What they did was they crippled you, in ways that were wellmeaning. When I say crippled I mean-Oh, I read a book last summer, a book called Dry-Long-So. It's an oral history of the core culture. But in that book the old people said, "There's nothing in the world as vicious and mean as a cracker. A cracker's the meanest thing." I mean, who are these people? This is what they held in, you see. "White people ought to be ashamed, all the energy they put into trying to keep us down." Things like that. But by holding it in and not passing it on, they sort of made a covenant with the future, and by virtue of that, of peace with white people in the future. So that they said, "I would rather see my children that naive. Let this bitterness hurt me but not them. In the hope that the same things won't happen again in the future." That was it-the contractual process, that was the initial giving or withholding with the consideration that the future has to give something back to you. That's what I meant when I said I was the result of a contractual process. And it works, it works well during times of racial peace, so to speak, because if the antagonism never resumes, you cancel what's due to you. But when there's no racial peace, you look back on those folks and say, "They were right." And it hurts you. It hurts you.

SHACOCHIS: You also said that the process led to people grasping for a provisional identity to hold on to. If the older generation starts the contractual process, protecting the next generation from the experiences they've had, and then when the young grow up and start having their own conflictshow does a provisional identity fit into that?

MCPHERSON: I was talking about race. Now this is going to sound kind of silly, I guess. One thing that Ralph Ellison taught me, not taught me, but affirmed for me in a very prideful and manly way, was that I need make no apology for my color or for where I came from. That I was a multi-generational American, and if you didn't know that you were also an American, even though your color was different, that was your problem. You belonged here. This was my country and no Grand Kleagle of the California Klan could say it was not. Now I'm not talking about ideology now, or patriotism. I'm talking about a basic identity that is anybody's by birth, but that black Americans have to struggle for much more than white Americans. They have heavier dues. But what do you do when you let go of those moorings in the black community, the things that are worked out in terms of how you deal with white folk when there's no guidance there, because the situation is new? You have to figure out some new way to survive. In Cambridge, for example, I saw a lot of black guys becoming studs because that was an easy fashion. But you could not have an identity outside the role of a stud. Or, if you went to Harvard, you became Harvardized. Your identity became that of a Harvard man. But you couldn't bring in anything else with you. On the white side you saw the white students, or young white people, identifying 
with some of the most shallow aspects of black American tradition. Adopting the language, becoming theatrical revolutionaries. You see what I'm trying to say? The props were there. You take those props and construct something, but it's just illusions, just part way along the process, the process being an endless one because we were going to be lawyers, but also something more given the uniqueness of our experience. The point is that every generation of black Americans is torn between going back to the certainties of their ancestral identity, and they're goaded by the norms and clubs of society saying "You are a black," and the desire to go ahead and finish that contractual process. That's what I was talking about. Does that make sense to you?

SHACOCHIS: Yeah, it does. The provisional identity is the mid-way point. See if this makes sense to you. It's a devil's advocate question. Is writing a provisional identity, or is it the antithesis of that?

MCPHERSON: I guess for me, all I can be is a writer. I'll be that in my spare time no matter what else I do.

SHACOCHIS: So it's the antithesis.

MCPHERSON: That's the way I wound up.

SHACOCHIS: Provisional identities are sort of like adolescent behavior. You play a role because the role makes you more secure in some way. And then after awhile you stop playing the role because you're more sure about yourself and you have a better awareness of who you are. So it's adolescent behavior in a way. Being a writer is a decision against that, it's the antithesis of provisional identity, at least for most serious writers. How do most people overcome their provisional identities, or do they?

MCPHERSON: They don't. They don't. That's why the entire American tradition is one of the theater. When American society is most American is when it's theatrical. It goes back to your question-we were talking earlier about an upper class: who is there to provide a model? What's out there? Who are your heroes? Football players. Basketball players. There are no models. If you look at the bestseller list now, you get the autobiographies of movie stars. A star is an actor, he's a craftsman. The roles are great-he's not great. What is that for a model?

SHACOCHIS: Most good models are usually very vulnerable and get their asses kicked.

MCPHERSON: Um hmm. I'm just saying that the country's still in process. It doesn't really know who it is because it has no sense of what it is. We're just trying to string along in order to get to the third act where things will be resolved. This country has no tragic sense because it has been nurtured by musical comedy and the soap opera. In American drama everything's resolved before the last scene. What do you do when things can't be resolved? 
You either grow or you die. I mean, when there are no traditions that make things meaningful before the last commercial comes on, you either say, "I don't understand, I give up," or you develop a tragic sense. And until the country develops that, it will lack maturity. We're just waiting for some excitement so we can sort of improvise a make-do ending.

SHACOCHIS: Right. We seem very addicted to the decadence of excitement. Okay, let me ask one more question. What do you hope for in the years ahead as a writer and as a person?

MCPHERSON: Well, my hopes are for myself as a person. I hope to master the art of being closer to other people who should be in my life, to help raise my daughter and give her all the love I can, to learn from the mistakes I've made in the past. Right now I want personal happiness more than I want to write a bestseller.

SHACOCHIS: There's a narrator in "Just Enough for the City" who says, "Lately I've been trying for a simple definition of love." Have you found one yet? I know that's a narrator speaking in a story, but-

MCPHERSON: No, because I don't think it can be that simple. But I think I've found it, just in human terms with my daughter Rachel, and even trying to see it in terms of a mate. But I learned this much. You don't look for it. If it's due you, it will come to you. I can't be any more profound than this. 